\title{
Correlates of genital Chlamydial trachomatis infection in a cohort of infertile women in Ibadan, Nigeria
}

\author{
Tinuade A. Ajani ${ }^{1}$, Timothy A. O. Oluwasola ${ }^{2 *}$, Chinenye G. Anaedobe ${ }^{3}$, Mustapha A. Ajani ${ }^{4}$, \\ Samuel A. Fayemiwo ${ }^{1,5}$, Rasheed A. Bakare ${ }^{1,5}$
}

\author{
${ }^{1}$ Department of Medical Microbiology, University College Hospital, Ibadan \\ ${ }^{2}$ Department of Obstetrics and Gynecology, University College Hospital, Ibadan and College of Medicine, University \\ of Ibadan \\ ${ }^{3}$ Department of Medical Microbiology and Parasitology, University of Abuja, FCT, Nigeria \\ ${ }^{4}$ Department of Histopathology, Babcock University, Ilishan-Remo, Ogun State \\ ${ }^{5}$ Department of Medical Microbiology, College of Medicine, University of Ibadan
}

Received: 07 July 2017

Accepted: 05 August 2017

\section{*Correspondence:}

Dr. Timothy A. O. Oluwasola,

E-mail: sesanoluwasola@yahoo.com

Copyright: (c) the author(s), publisher and licensee Medip Academy. This is an open-access article distributed under the terms of the Creative Commons Attribution Non-Commercial License, which permits unrestricted non-commercial use, distribution, and reproduction in any medium, provided the original work is properly cited.

\begin{abstract}
Background: Genital Chlamydial trachomatis infection, though often asymptomatic, is an established indirect causative agent of female infertility via its activities on the tubal physiology. Many risk factors are postulated for its acquisition and the main thrust of this study was to establish the organisms' correlates among infertile women attending gynaecologic clinic in Ibadan.

Methods: A systematic sampling technique was used on each selected day to recruit women who met the inclusion criteria into the study using a sampling frame of 2. Interviewer-administered questionnaires were used to obtain attributes considered as risk factors for acquiring genital Chlamydia trachomatis infection from 150 consenting infertile women between January and November 2015. These attributes included sexual history, social status, alcohol intake and past history of sexually transmitted infections (STIs). Blood samples and endocervical swabs were subsequently taken for detection of $C$. trachomatis infection using polymerase chain reaction (PCR). Data analysis was done using SPSS version 20.0.

Results: The mean age of the respondents was $34.1 \pm 5.6$ years and $7.30 \%$ were positive for C. trachomatis. Chlamydia trachomatis infection was significantly associated with past history of gonorrhoea, history of multiple sexual partners, husband that has other sexual partners and lifetime sexual partners greater than one.

Conclusions: The prevalence of asymptomatic $C$. trachomatis among infertile women indicated the pathogen as a potential aetiologic agent of female infertility and supported the asymptomatic nature of the infection. The risk factors found to be associated with the organisms' infection lend out further support to the sexual transmissibility of $C$. trachomatis.
\end{abstract}

Keywords: Asymptomatic, C. trachomatis, Genital, Infertility, PCR, STIs

\section{INTRODUCTION}

Chlamydia trachomatis is among the most common sexually transmitted bacterial organisms, worldwide. ${ }^{1}$ It is the causative agent for several diseases including trachoma, urogenital infections, Chlamydia conjunctivitis, infant pneumonia, and lymphogranuloma venereum. $^{2}$

Two third of cases of Chlamydial infections worldwide occurred in the developing countries and the incidence of 
the infection has continued to rise every year in both industrialized and developing countries. ${ }^{1}$

Infertility is a worldwide problem affecting more than 15$20 \%$ of married couples and commonly caused, in most developing countries, by tubal damage in women. ${ }^{3}$ Pelvic infections from sexually transmitted organisms especially C. trachomatis have remained the commonest cause of tubal occlusion. ${ }^{3,4}$ Genital $C$. trachomatis infections in women are usually asymptomatic or present with less severe symptoms than other sexually transmitted diseases thus allowing the infection go unnoticed till secondary or tertiary symptoms develop with far reaching consequences such as infertility. ${ }^{2,5} \mathrm{~A}$ study in Ibadan found the prevalence of Chlamydia cervicitis to be $17.6 \%$ among women undergoing hysterosalphingography for infertility evaluation while several studies have proven that $C$. trachomatis infections rates are higher among infertile than fertile women. ${ }^{3,5-15}$

Patients with positive Chlamydia assay are 1.7 times at risk of infertility compared with patients with negative assay..$^{5}$ A study reported that Chlamydia trachomatis IgG was significantly higher among patients presenting with infertility than those that did not. ${ }^{16}$ A study also reported that both past and current Chlamydial infections are strongly statistically significant in women with secondary infertility while another study reported a prevalence of $28.1 \%$ among women presenting with infertility in a clinic. ${ }^{13,17}$

In developing countries, the prevalence of lower genital tract chlamydial infection in sexually active women is reported to be $26 \% .^{18}$ Fifteen million new cases of $C$. trachomatis occur in Africa while 45 million new cases are reported in Southern Asia every year. ${ }^{19}$ In Nigeria, the prevalence of C. trachomatis was $18.2 \%$ in Lagos, $17.6 \%$ in Ibadan and $22 \%$ in Calabar among women undergoing evaluation for infertility. ${ }^{6,8,14}$ Other studies in Nigeria among other populations have reported varied prevalence of Chlamydia infections which ranged from $6.7 \%$ to $60 \%$ in Lagos, Zaria, Benin, Enugu, Port-Harcourt and Kano. ${ }^{4,9,20-26}$

Numerous risk factors and sexual behaviour have been associated with acquisition of genital Chlamydia infection. Studies done on the prevalence and risk factors for genital Chlamydia infection found that the main risk factors for $C$. trachomatis infection are age, irregular sexual relationships and change of sexual partners, failure to use (or erratic use) of barrier contraception during intercourse, and insufficient knowledge about sexual life and care for one's sexual health. ${ }^{27,28}$

Another study in Germany found that genital Chlamydia infection was associated with alcoholism, high use of marijuana and cigarettes, lower social status, oral contraceptive use and pregnancy. ${ }^{29}$ In another study, additional risk factors reported included duration of marriage, partners living away from each other, age (40\% of adolescent women are currently infected), educational level, unprotected sex with an infected partner and multiple sexual partners. ${ }^{30}$ A systematic review and metaanalysis done in Australia found a trend of higher Chlamydia prevalence in younger populations. ${ }^{31}$ In Nigeria, risk factors found to be associated with Chlamydia trachomatis infection include multiple sexual partners, irregular contraceptive usage and past history of sexually transmitted infections. ${ }^{32}$

The objective of this study was to determine the risk factors predisposing to acquisition of genital Chlamydia trachomatis infection among women presenting with infertility in University College Hospital, Ibadan.

\section{METHODS}

This was a descriptive cross-sectional study in which women presenting with infertility and asymptomatic for Chlamydia trachomatis infection at the Gynaecology clinic of the University College Hospital were recruited. Questionnaires were administered between January and November 2015 to obtain respondent's attributes considered as risk factors for acquiring genital Chlamydia trachomatis infection. These attributes include sexual history, social status, alcohol intake and past history of sexually transmitted infections (STIs).

Blood samples and endocervical swabs were subsequently taken from the consenting infertile women. Only women who presented with infertility at the gynaecology clinic of the UCH, Ibadan, Nigeria and consented to the study were included while those who presented with infertility but have symptoms suggestive of genital Chlamydia trachomatis infection such as dysuria, abnormal vaginal discharge, abnormal menstrual bleeding, post-coital bleeding and lower abdominal pain were excluded. In addition, women who used antibiotics in the preceding 6 weeks and those who refuse to consent were excluded from the study.

\section{Sampling technique}

A simple random sampling using balloting technique was used to select one day out of the three clinic days for the study weekly. A systematic sampling technique was used on the selected day to recruit women who met the inclusion criteria into the study. Using a sampling interval of 2 for weekly patient selection, the first patient is recruited by ballot and thereafter every alternate patient was selected until the desired sample, which were 10 for each clinic day was met.

\section{Data manangement}

Data collected was subjected to descriptive and inferential statistical analysis using the SPSS version 20.0 software. In addition, means and standard deviation were derived for quantitative variables, while qualitative variables were summarized as proportions. Chi square 
test was used to assess association between qualitative variables. $\mathrm{P}$ values $\leq 0.05$ was considered statistically significant.

Variables of interest were past history of infection with Neisseria gonorrhea or any other sexually transmitted diseases (STD), use of condom with a sexual partner and past history of multiple sexual partners.

\section{RESULTS}

It was a cross- sectional hospital based study that involved 150 consenting women presenting with infertility at the gynaecology clinic of the UCH, Ibadan. Their mean age was $34.1 \pm 5.6$ years.

Majority, 89 (59.3\%), were self-employed and almost three-quarters, 108 (72\%) earn above the national minimum wage.

Table 1: Socio-demographic characteristics of the respondents.

\begin{tabular}{|c|c|c|}
\hline $\begin{array}{l}\text { Socio-demographic } \\
\text { characteristics }\end{array}$ & Frequency & Percentage \\
\hline \multicolumn{3}{|l|}{ Age groups (in years) } \\
\hline $20-29$ & 29 & 19.3 \\
\hline $30-39$ & 96 & 64.0 \\
\hline$\geq 40$ & 25 & 16.7 \\
\hline \multicolumn{3}{|l|}{ Religion } \\
\hline Christianity & 92 & 61.3 \\
\hline Islam & 58 & 38.7 \\
\hline \multicolumn{3}{|l|}{ Marital status } \\
\hline Single & 11 & 7.3 \\
\hline Married & 136 & 90.7 \\
\hline Divorced & 3 & 2.0 \\
\hline \multicolumn{3}{|l|}{ Family setting } \\
\hline Monogamy & 129 & 86.0 \\
\hline Polygamy & 21 & 14.0 \\
\hline \multicolumn{3}{|l|}{ Education } \\
\hline Primary uncompleted & 2 & 1.3 \\
\hline Primary completed & 8 & 5.3 \\
\hline Secondary uncompleted & 7 & 4.7 \\
\hline Secondary completed & 44 & 29.3 \\
\hline Post-secondary & 27 & 18.0 \\
\hline Tertiary & 62 & 41.4 \\
\hline \multicolumn{3}{|l|}{ Income (in naira) } \\
\hline$<18,000$ & 42 & 28.0 \\
\hline$\geq 18,000$ & 108 & 72.0 \\
\hline \multicolumn{3}{|l|}{ Employment } \\
\hline Self-employed & 89 & 59.3 \\
\hline $\begin{array}{l}\text { Employed by } \\
\text { government/private }\end{array}$ & 46 & 30.7 \\
\hline Unemployed & 10 & 6.7 \\
\hline Housewife & 1 & 0.7 \\
\hline Student & 2 & 1.3 \\
\hline Others & 2 & 1.3 \\
\hline
\end{tabular}

The other socio-demographic characteristics are illustrated in the Table 1. In addition, $116(77.3 \%)$ were HIV negative and only 5 (3.3\%) take alcohol (Table 2 ).

Table 2: Gynaecological history and sexual behaviour of respondents.

\begin{tabular}{|c|c|c|}
\hline Variables & Frequency & Percentage \\
\hline \multicolumn{3}{|c|}{ Type of infertility } \\
\hline Primary & 61 & 40.7 \\
\hline Secondary & 89 & 59.3 \\
\hline \multicolumn{3}{|c|}{ Previous history of abortion } \\
\hline Yes & 56 & 37.3 \\
\hline No & 94 & 62.7 \\
\hline \multicolumn{3}{|c|}{ Use condom with sexual partner } \\
\hline Yes & 27 & 18.0 \\
\hline No & 123 & 82.0 \\
\hline \multicolumn{3}{|c|}{ New sex partner in the last 3 months } \\
\hline Yes & 8 & 5.3 \\
\hline No & 142 & 94.7 \\
\hline \multicolumn{3}{|c|}{ Long distance driver husband } \\
\hline Yes & 15 & 10.0 \\
\hline No & 135 & 90.0 \\
\hline \multicolumn{3}{|c|}{ Alcohol intake } \\
\hline Yes & 5 & 3.3 \\
\hline No & 145 & 96.7 \\
\hline \multicolumn{3}{|c|}{ Number of Sex partners presently } \\
\hline 1 & 147 & 98.0 \\
\hline 2 or more & 3 & 2.0 \\
\hline \multicolumn{3}{|c|}{ Number of lifetime sexual partners } \\
\hline 1 & 76 & 50.7 \\
\hline$>1$ & 74 & 49.3 \\
\hline \multicolumn{3}{|c|}{ Husband has other sexual partners } \\
\hline Certainly yes & 21 & 14.0 \\
\hline Certainly no & 71 & 47.3 \\
\hline Not sure & 58 & 38.7 \\
\hline \multicolumn{3}{|c|}{ History of Multiple sex partner } \\
\hline Yes & 65 & 43.3 \\
\hline No & 85 & 56.7 \\
\hline \multicolumn{3}{|l|}{ HIV status } \\
\hline Positive & 8 & 5.3 \\
\hline Negative & 116 & 77.3 \\
\hline Unknown & 26 & 17.3 \\
\hline
\end{tabular}

The prevalence of Chlamydia trachomatis, using PCR, was $7.30 \%$. Among the respondents, Chlamydia trachomatis infection was significantly associated with past history of gonorrhoea, history of multiple sexual partners, husband that has other sexual partners and lifetime sexual partners greater than one, (Tables 3 ).

The logistic regression analysis showed that respondents who had past history of gonorrhoea were 8.37 times more likely to have genital Chlamydia trachomatis infection than those that did not have the infection.

History of multiple sexual partners was strongly associated with genital $C$. trachomatis infection, (Tables 3 and 4). 
Table 3: Factors associated with chlamydia trachomatis infection in the respondents.

\begin{tabular}{|c|c|c|c|c|c|}
\hline \multirow{2}{*}{ Variable } & \multicolumn{2}{|c|}{ Chlamydia infection } & \multirow{2}{*}{ df } & \multirow{2}{*}{$\mathbf{X}^{2}$} & \multirow{2}{*}{ p-value } \\
\hline & Yes $(\%)$ & No $(\%)$ & & & \\
\hline \multicolumn{6}{|c|}{ Grouped Age (in years) } \\
\hline $20-29$ & $2(6.9)$ & $27(93.1)$ & \multirow{3}{*}{2} & \multirow{3}{*}{0.025} & \multirow{3}{*}{0.988} \\
\hline $30-39$ & $7(7.3)$ & $89(92.7)$ & & & \\
\hline$\geq 40$ & $2(8.0)$ & $23(92.0)$ & & & \\
\hline \multicolumn{6}{|c|}{ Past history of Gonorrhoea } \\
\hline Yes & $9(17.3)$ & $43(82.7)$ & \multirow{2}{*}{1} & \multirow{2}{*}{8.494} & \multirow{2}{*}{0.0036} \\
\hline No & $2(2.0)$ & $96(98.0)$ & & & \\
\hline \multicolumn{6}{|c|}{ History of Multiple sex partner } \\
\hline Yes & $9(13.8)$ & $56(86.2)$ & \multirow[b]{2}{*}{1} & \multirow{2}{*}{7.2} & \multirow{2}{*}{0.007} \\
\hline No & $2(2.4)$ & $83(97.6)$ & & & \\
\hline \multicolumn{6}{|l|}{ HIV Status } \\
\hline Positive & $1(12.5)$ & $7(87.5)$ & \multirow{3}{*}{2} & \multirow{3}{*}{0.352} & \multirow{3}{*}{0.839} \\
\hline Negative & $8(6.9)$ & $108(93.1)$ & & & \\
\hline Unknown & $2(7.7)$ & $24(92.3)$ & & & \\
\hline \multicolumn{6}{|c|}{ Husband has other sex partners } \\
\hline Certainly yes & $9(42.9)$ & $12(57.1)$ & \multirow{3}{*}{2} & \multirow{3}{*}{45.4} & \multirow{3}{*}{$<0.001$} \\
\hline Certainly no & $1(1.4)$ & $70(98.6)$ & & & \\
\hline Not sure & $1(1.7)$ & $57(98.3)$ & & & \\
\hline \multicolumn{6}{|c|}{ Lifetime sexual partners } \\
\hline One & $2(2.6)$ & $74(97.4)$ & \multirow{2}{*}{1} & \multirow{2}{*}{5.0} & \multirow{2}{*}{0.025} \\
\hline$>$ One & $9(12.2)$ & $65(87.8)$ & & & \\
\hline
\end{tabular}

Table 4: Logistic regression analysis.

\begin{tabular}{|c|c|c|c|}
\hline Variables & $\begin{array}{l}\text { Odds } \\
\text { Ratio }\end{array}$ & $\begin{array}{l}95 \% \\
\text { Confidence } \\
\text { Interval }\end{array}$ & p-value \\
\hline \multicolumn{4}{|c|}{ Past history of Gonorrhoea } \\
\hline $\begin{array}{l}\text { Yes } \\
\text { No (R) } \\
\text { Don’t know }\end{array}$ & 8.37 & $\begin{array}{l}1.60-81.75 \\
0.00-27.84\end{array}$ & 0.002 \\
\hline \multicolumn{4}{|c|}{ History of Multiple sex partner } \\
\hline $\begin{array}{l}\text { Yes } \\
\text { No }(\mathrm{R})\end{array}$ & 6.67 & $1.30-64.95$ & 0.007 \\
\hline \multicolumn{4}{|c|}{ Husband has other sex partners } \\
\hline $\begin{array}{l}\text { Certainly yes } \\
\text { Certainly no }(\mathrm{R}) \\
\text { Not sure }\end{array}$ & 52.5 & $\begin{array}{l}4.09-226.61 \\
0.02-97.76\end{array}$ & $<0.0001$ \\
\hline \multicolumn{4}{|c|}{ Lifetime sexual partners } \\
\hline $\begin{array}{l}\text { One }(\mathrm{R}) \\
>\text { One }\end{array}$ & 5.12 & $0.98-35.72$ & 0.025 \\
\hline
\end{tabular}

\section{DISCUSSION}

Genital Chlamydia trachomatis is known to be a cause of female infertility although often unrecognized because of its asymptomatic nature. This study was done to determine the correlates of asymptomatic genital $C$. trachomatis infection among infertile women. Using PCR, prevalence rate was $7.30 \%$ thus highlighting the asymptomatic nature of Chlamydia trachomatis. ${ }^{2,5}$ This prevalence rate is also similar to rates obtained in studies from Argentina, Sudan and Iran from where prevalence of $7.27 \%, 10.5 \%$ and $12.4 \%$ were reported respectively but higher than $1.6 \%$ reported in Ghana. ${ }^{3,7,33,34}$ These different prevalent rates might be due to socio-cultural differences and practices across these countries.

In Nigeria, there is paucity of data on the prevalence of asymptomatic genital Chlamydia trachomatis infection among infertile women based on PCR. In a study conducted by Otoikhian et al, the prevalence of Chlamydia trachomatis among asymptomatic adolescents in Nigeria in which PCR was used as a diagnostic method was found to be $52.63 \% .^{26}$ This prevalence was much higher than what we obtained in the present study. The reason for this difference might be due to the different study populations that participated in their studies. It has been established that the prevalence of Chlamydia trachomatis infection is higher among adolescents. ${ }^{1}$

Past history of Neisseria gonorrheae or other STIs, multiple sexual partners, husband that had other sex partners and lifetime sex partner $>1$ remained strongly associated risk factors for $C$. trachomatis infection. Several studies have previously demonstrated positive correlation between multiple sexual partners and increased risk for Chlamydia trachomatis infection. ${ }^{2,3,28,32,35}$ Asymptomatic men have been found to have large reservoir of Chlamydia trachomatis which could potentially and repeatedly, re-infect their partners. ${ }^{36}$ The strong association with husbands who had other sex partners found in this study however suggested that 
transmission may require repeated exposure to an infected partner, which would be facilitated by the longer-term partnerships that are characteristic of individuals who cohabit.

The lack of association between $C$. trachomatis and the non-use of condom in this study is similar to an earlier systematic review by Navarro et al but in contrast with a previous research which reported a positive relationship. ${ }^{37.38}$ This lack of association might be because the respondents, being infertile women were unlikely to be on any form of contraception. The association between Chlamydia trachomatis and past history of Neisseria gonorrhoea or other STIs in this study is similar to that of other studies although Tukur et al did not find any of such association between $C$. trachomatis infection and past history of STI. ${ }^{20,32,39-41}$ The association corroborated the fact that previous STIs, especially gonorrhoea, increase the risk for chlamydia infection. ${ }^{8}$ The risk of infertility thus increases with each successive episode of infection. ${ }^{10,42}$

In summary, the prevalence of asymptomatic $C$. trachomatis among infertile women indicated the pathogen as a potential aetiologic agent of female infertility and supported the asymptomatic nature of the infection. The risk factors found to be associated with the organism infection lend out further support to the sexual transmissibility of $C$. trachomatis. Understanding the risk factors will enable targeted efforts at their prevention in order to reduce the burden of infertility in Nigeria. There should be preventive programme strategies such as education on risky sexual behaviours among women of reproductive age group or sexually active individuals.

\section{ACKNOWLEDGMENTS}

Authors would like to appreciate the Head of Department and Staff of the Gynaecology Clinic of University College Hospital Ibadan, Oyo State, for their cooperation and support during the study.

Funding: No funding sources Conflict of interest: None declared

Ethical approval: The study was approved by the Institutional Ethics Committee

\section{REFERENCES}

1. Cuffini C, Bottiglieri M, Kiguen X, E. Alonso C, Valdes Deimundo R, Beatriz Isa M, et al. Molecular Epidemiology of Genital Chlamydia Trachomatis Infection in Asymptomatic Adolescent-Young People. J Microbiol Res. 2012;2(4):114-7.

2. Sturm-Ramirez K, Brumblay H, Diop K, Guèye-Ndiaye A, Sankalé JL, Thior I et al. Molecular epidemiology of genital Chlamydia trachomatis infection in high-risk women in Senegal, West Africa. J Clin Microbiol. 2000;38(1):138-45.
3. Rashidi BH, Chamani-Tabriz L, Haghollahi F, JeddiTehrani M, Naghizadeh MM, Shariat M, et al. Effects of Chlamydia trachomatis infection on fertility; a casecontrol study. J Reprod Infertil. 2013;14(2):67-72.

4. Nsonwu-Anyanwu A, Charles-Davies M, Oni A, Taiwo V, Bello FA. Chlamydial Infection, plasma peroxidation and obesity in tubal infertility. Ann Ibadan Postgrad Med. 2011;9(2):84-9.

5. Tayo AO, Akinola IO, Ottun TA, Babatunde A, Shakunle B. Chlamydia infection and infertility: any relationship? The Lagos State University Teaching Hospital experience. Int J Med Med Sci. 2011;1(1):179.

6. Atalabi OM, Fayemiwo SA, Oladokun AA, Bakare RA. Pattern of asymptomatic sexually transmitted infections in women undergoing hysterosalpingography for infertility evaluation in Ibadan Nigeria. Trop J Obstet Gynecol. 2013;30(2):91-8.

7. Siemer J, Theile O, Larbi Y, Fasching PA, Danso KA, Kreienberg R, et al. Chlamydia trachomatis Infection as a risk factor for infertility among women in West Africa. J Chem Inf Model. 2008;78(1):323-7.

8. Oloyede O, Fakoya T, Oloyede A, Alayo A. Prevalence and awareness about Chlamydial infection in women undergoing infertility evaluation in Lagos, Nigeria. Int $\mathbf{J}$ Heal Res. 2009;2(2):157-62.

9. Nwankwo EO, Sadiq MN. Prevalence of Chlamydia trachomatis infection among patients attending infertility and sexually transmitted diseases clinic (STD) in Kano, North Western Nigeria. Afr Health Sci. 2014; 14 (3):672-8.

10. Okonofua FE, Ako-Nai KA, Dighitoghi MD. Lower genital tract infections in infertile Nigerian women compared with controls. Genitourin Med. 1995;71(3):163-8.

11. Morhason-Bello I, Ojengbede O, Oladokun A, Adedokun B, Ajayi A, Adeyanju A, et al. The prevalence and outcome of asymptomatic chlamydial infection screening among infertile women attending gynecological clinic in Ibadan, South West Nigeria. Ann Med Heal Sci Res. 2014;4(2):253-7.

12. Musa M, Joel B, Lenard A, Joseph N, Ronald M, Julius $\mathrm{M}$, et al. Prevalence and factors associated with genital chlamydial infections among women attending the gynecology clinic At Mbarara Regional Referral Hospital. J Heal Med Nurs. 2016;26:20-7.

13. Malik A, Jain S, Hakim S, Shukla I, Rizvi M. Chlamydia trachomatis infection and female infertility. Indian J Med Res. 2006;123:770-5.

14. Inyang-Etoh $P$, Ogban $G$, Inyang-Etoh E, Useh M, Etuk $\mathrm{S}$. Prevalence of Chlamydia trachomatis infection among women attending infertility clinics in Calabar, Nigeria. Niger J Heal Biomed Sci. Department of Physiology, College of Medicine of the University of Lagos. 2009;8(1).

15. Jeremiah I, Okike O, Akani C. The prevalence of serum immunoglobulin $\mathrm{g}$ antibody to Chlamydia trachomatis in subfertile women presenting at the university of port harcourt teaching hospital, Nigeria. Int J Biomed Sci. 2011;7(2):120-4.

16. Miron ND, Socolov D, Mares M, Anton G, Nastasa V, Moraru RF, et al. Bacteriological agents which play a 
role in the development of infertility. Acta Microbiol Immunol Hung. 2013;60(1):41-53.

17. Malik A, Jain S, Rizvi M, Shukla I, Hakim S. Chlamydia trachomatis infection in women with secondary infertility. Fertil Steril. 2009;91(1):91-5.

18. Tiwara S, Passey M, Clegg A, Mgone C, Lupiwa S, Suve N, et al. High prevalence of trichomonal vaginitis and chlamydial cervicitis among a rural population in the highlands of Papua New Guinea. P N G Med J. 1996;39(3):234-8.

19. Caro Vergara MR, Buendia Marin AJ, Rio Alonso L del, Cuello Gijon F, Ortega Hernandez N, Gallego Ruiz $\mathrm{MC}$, et al. Chlamydia trachomatis genital infection: immunity and prospects for vaccine development. Inmunologia. 2005;24(3):298-312.

20. Tukur J, Shittu SO, Abdul AM. A case control study of active genital Chlamydia trachomatis infection among patients with tubal infertility in northern Nigeria. Trop Doct. 2006;36:14-6.

21. Isibor J, Ugbomoiko D, Nwobu G, Ekundayo A, Enweani I, Okogun G. Detection of chlamydia antigen in cervical specimens from antenatal clinic attendees in Benin City, Nigeria. African J Clin Exp Microbiol. 2005;6(3).

22. Ikeme AC, Ezegwui HU, Ikeako LC, Agbata I, Agbata E. Seroprevalence of Chlamydia trachomatis in Enugu, Nigeria. Niger J Clin Pract. 2011;14(2):176-80.

23. Arinze AUH, Onyebuchi NV, Israel J. Genital chlamydia trachomatis infection among female undergraduate students of University of Port Harcourt, Nigeria. Niger Med J. 2014;55(1):9-13.

24. Ella EE, Shenge H, Ajoge HO. Prevalence of Chlamydia trachomatis among female students attending a selected University Health Services in Zaria, Kaduna State, Nigeria. Int J Eng Sci. 2013;2(11):54-7.

25. Enwuru $\mathrm{CP}$, Umeh. Asymptomatic carriage of chlamydia trachomatis among young adults in Owerri, South East Nigeria. IOSR J Nurs Heal Sci. 2014;3(2):49-53.

26. Otoikhian CSO, Okoror LE, Ekakitie AO. Polymerase chain reaction (PCR) a genetic tool for assessing Chlamydia Trachomatis in Mid-stream urine of asymptomatic females. Int $\mathrm{J}$ Life $\mathrm{Sc}$ Bt Pharm Res. 2012;1(4):212-21.

27. Kucinskiene V, Sutaite I, Valiukeviciene S, Milasauskiene Z, Domeika M. Prevalence and risk factors of genital Chlamydia trachomatis infection. Medicina (Kaunas). 2006;42 (11):885-94.

28. 28. León SR, Konda KA, Klausner JD, Jones FR, Cáceres CF, Coates TJ, et al. Chlamydia trachomatis infection and associated risk factors in a low-income marginalized urban population in coastal Peru. Rev Panam Salud Publica. 2009;26(1):39-45.

29. Haar K, Bremer V, Houareau C, Meyer T, Desai S, Thamm M, et al. Risk factors for Chlamydia trachomatis infection in adolescents: Results from a representative population-based survey in Germany, 2003-2006. Eurosurveillance. 2013;18(34):2003-6.

30. El Qouqa IA, Shubair ME, Al Jarousha AM, Sharif FA. Prevalence of Chlamydia trachomatis among women attending gynecology and infertility clinics in Gaza, Palestine. Int J Infect Dis. 2009;13(3):334-41.

31. Lewis D, Newton DC, Guy RJ, Ali H, Chen MY, Fairley CK, et al. The prevalence of Chlamydia trachomatis infection in Australia: a systematic review and meta-analysis. BMC Infect Dis. 2012;12(1):113-30.

32. Wariso K, Odigie J, Eyaru S. Prevalence of Chlamydia trachomatis Infection among Female Undergraduates of the University of Port Harcourt Using Strand Displacement and Amplification [SDA] Technique. Niger Heal J. 2012;12(2):35-8.

33. de Jesús De Haro-Cruz M, Deleón-Rodriguez I, Escobedo-Guerra M, López-Hurtado M, ArteagaTroncoso G, Ortiz-Ibarra F, et al. Genotyping of Chlamydia trachomatis from endocervical specimens of infertile Mexican women. Enferm Infecc Microbiol Clin. 2011;29(2):102-8.

34. Mohammed A. Molecular detection of Chlamydia trachomatis among gynecological patients attending Khartoum Teaching Hospital. J Bacteriol Res. 2012;4(4):42-5.

35. Salfa MC, Latino MA, Mario D De, Intinis G De, Camoni L, Raimondo $\mathrm{M}$, et al. Prevalence and determinants of Chlamydia trachomatis infection among sexually active women in Turin, Italy. Ital J Public Health. 2012;8(3):295-301.

36. Bakare RA, Oni AA, Umar US, Okesola AO, Kehinde AO, Fayemiwo SA, et al. Non-gonococcal urethritis due to Chlamydia trachomatis: the Ibadan experience. African J Med Med Sci. 2002;31(1):17-20.

37. Navarro C, Jolly A, Nair R, Chen Y. Risk factors for genital chlamydial infection. Can $\mathrm{J}$ Infect Dis. 2002;13(3):195-207.

38. Bakhtiari A, Firoozjahi A. Chlamydia trachomatis infection in women attending health centres in Babol: prevalence and risk factors. East Mediterr Heal J. 2007;13(5):1124-31.

39. Yazdi JZ, Khorramizadeh M, Badami N, Kazemi B, Aminharati F, Eftekhar Z, et al. Comparative assessment of Chlamydia trachomatis infection in Iranian women with cervicitis: a cross-sectional study. Iran J Public Health. 2006;35(2):69-75.

40. 40. Mawak JD, Dashe N, Agabi YA, Panshak BW. Prevalence of genital chlamydia trachomatis infection among gynecologic clinic attendees in jos, nigeria. Shiraz E Med J. 2011;12(2):100-6.

41. Masese L, Baeten JM, Richardson BA, Deya R, Kabare $\mathrm{E}$, Bukusi E, et al. Incidence and correlates of Chlamydia trachomatis infection in a high-risk cohort of Kenyan women. Sex Transm Dis. 2013;40(3):221-5.

42. Geisler WM, James AB. Chlamydial and gonococcal infections in women seeking pregnancy testing at family-planning clinics. Am J Obstet Gynecol. 2008;198.

Cite this article as: Ajani TA, Oluwasola TAO, Anaedobe CG, Ajani MA, Fayemiwo SA, Bakare RA. Correlates of genital Chlamydial trachomatis infection in a cohort of infertile women in Ibadan, Nigeria. Int J Reprod Contracept Obstet Gynecol 2017;6:3754-9. 